(C) [2008] IEEE. Reprinted, with permission, from Zhan, Yuedong; Guo, Youguang; Zhu, Jianguo; Wang, Hua. 2008, Power Converters and Controllers for UPS Applications with Backup PEM Fuel Cell', Proceedings of the 43rd IEEE Industry Applications Society Annual Meeting, pp. 1-8.This material is posted here with permission of the IEEE. Such permission of the IEEE does not in any way imply IEEE endorsement of any of the University of Technology, Sydney's products or services. Internal or personal use of this material is permitted. However, permission to reprint/republish this material for advertising or promotional purposes or for creating new collective works for resale or redistribution must be obtained from the IEEE by writing to pubs-permissions@ieee.org. By choosing to view this document, you agree to all provisions of the copyright laws protecting it. 


\section{Power Converters and Controllers for UPS Applications with Backup PEM Fuel Cell}

\author{
Yuedong Zhan \\ Department of Automation \\ Kunming University of Science and \\ Technology \\ Kunming, China \\ ydzhan@163.com
}

\author{
Youguang Guo, Jianguo Zhu \\ Faculty of Engineering \\ University of Technology, Sydney \\ Sydney, Australia \\ youguang@eng.uts.edu.au, \\ joe@eng.uts.edu.au
}

\author{
Hua Wang \\ Department of Automation \\ Kunming University of Science and \\ Technology \\ Kunming, China
}

\begin{abstract}
This paper studies the practical cost-effective DC/DC converter, DC/AC inverter and AC/DC rectifier for an uninterruptible power supply (UPS) system with backup proton exchange membrane fuel cell (PEMFC). Furthermore, a comprehensive controller for the PEMFC is designed according to the change of the load, while the energy storage elements, such as battery and ultracapacitor, are chosen in order to compensate the slow dynamic response of PEMFC and to meet the sudden peak load energy demand. The designed power converters can supply high quality power with flexible conversion functions, leading to the establishment of reliable power management for UPS applications. Finally, a suitable control strategy and technique, capable of coping with the change of the load for PEMFC and realizing the energy managements of UPS hybrid system, is implemented. The performances of the proposed power converters and controllers are evaluated by experimental results, showing that the developed UPS system with backup PEMFC and battery power sources is suitable for industry applications.
\end{abstract}

Keywords- proton exchange membrane fuel cell (PEMFC); power converters; comprehensive controller component; uninterruptible power supply (UPS)

\section{INTRODUCTION}

An uninterruptible power supply (UPS) system is a power conditioning equipment, which has become very popular for applications in computers, medical/life support systems, telecommunication and industrial controls. Its main function is to continuously feed loads with high quality power even when a strong perturbation occurs in the utility grid [1]. A high performance UPS system should have a clean output voltage with low total harmonic distortion for both linear and nonlinear loads, high efficiency, great reliability and fast transient response for sudden power grid failure and load change [2]. Therefore, UPS systems that can keep the information and data from being destroyed are desired. Particularly, with the popularization of personal computers and Internet, low capacity UPS products will take an increscent part in the industrial and domestic markets. Due to the highly competitive world market, many technical advances, such as higher power density, higher efficiency and intellectualized control are implemented into the UPS system.

The integration of fuel cells with UPS would become a potential market application for extended run-time UPS. Due to high electrical efficiency, flexibility with respect to power and capacity, long lifetime and no pollutions, fuel cells are rapidly becoming a significant source of power in our society, and their applications in a variety of aspects are inevitable [3]. Among fuel cell technologies, the liquid-fed direct methanol fuel cell and the proton exchange membrane fuel cell (PEMFC) based on hydrogen are the most promising [4]. To a long-term demand with large power capacities of UPS, hydrogen systems appear as strong contenders to replace batteries, especially in grid-connected applications where reliable power supply with good quality is required, because an interruptions could last long time, e.g. over 8 hours $[5,6]$. However, compared with the fuel cells, lead-acid rechargeable batteries have rapid transient response with little warm up or start up time, and their specific power capability is also much higher than that of fuel cells [7]. As a result, by combining the fuel cells with small capacity batteries or ultracapacitors, the PEMFC/battery hybrid UPS system can take the advantages of all the individual devices, and may meet the requirements for the above mentioned applications regarding both high power and high energy densities.

Regarding the power converter, the latest research and development show that for a UPS system with hybrid PEMFC and battery/ultracapacitor power sources, there are three basic configurations of power conditioning system (PCS) [8, 9], which are (1) the isolation high frequency DC/DC converter for fuel cell connecting high voltage battery; (2) the nonisolation DC/DC converter for fuel cell connecting low voltage battery; and (3) the isolation high frequency DC/DC converter for fuel cell and bi-directional DC/DC converter for low voltage battery. In the related field of a fuel cell powered hybrid electric vehicles $[10,11]$, the latest research shows that there are three categories: (1) the multi-input converter using high/low voltage sources; (2) the multi-input converter based on flux additivity, and (3) the multi-input DC/DC converter for energy storage units [12].

In this paper, based on the concept adopting matured technology for the components of the UPS hybrid system, the double charging of the battery through the AC/DC charger or the PEMFC and to be easy to develop serial products, an industrial UPS system with backup PEMFC and battery power sources is developed in order to supply the load with a typical power $(500 \mathrm{~W}, 220 \mathrm{VAC}$ and $50 \mathrm{~Hz}$ ). The proposed power 
converters, such as the AC/DC rectifier, the DC/DC converter, and the DC/AC inverter, are designed and evaluated through the experimental tests on a laboratory prototype. In order to improve the performance of the PEMFC, a comprehensive controller is introduced. Fig. 1 illustrates schematically the structure of a single-phase high-frequency cost-effective UPS system with backup PEMFC and battery hybrid power sources.

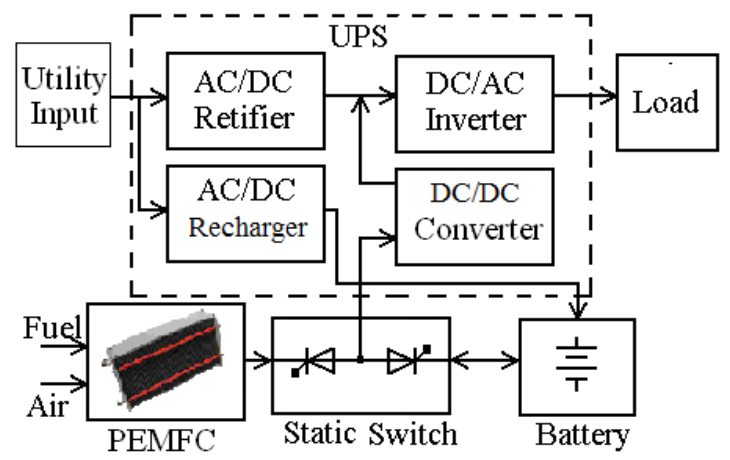

Figure 1. Scheme of UPS with backup PEMFC and battery power sources

\section{CONTROLler Design OF PEMFC POWERED System}

Aiming to conveniently collect the data and setup parameters for PEMFC and UPS and to properly choose the power, voltage and size of the PEMFC stack according to the cost of the PEMFC and the battery voltage, a comprehensive controller of the PEMFC generating and testing system is designed as shown in Fig. 2, consisting of the PEMFC stack, water-cooling and air-cooling, $\mathrm{H}_{2}$ humidifying and filtering, and monitoring of the temperature and pressure for the stack. The data acquisition and control devices and software have been developed and can be used to control the whole process of the PEMFC generating and testing system and to measure the operational parameters, such as the work temperature, voltage and current, pressure, input and output mass flows, humidity of the hydrogen and air/oxygen, the voltage and current of the battery and so on.

For the experimental setup, a $500 \mathrm{~W}$ PEMFC stack has been employed [13]. It is a self-humidified 32-cell stack with electrode area of $64 \mathrm{~cm}^{2}$. Four fans are used to supply the air and cool the stack, which has a maximum operating temperature of $65{ }^{\circ} \mathrm{C}$ and an operating pressure of 5 psi for hydrogen and 10 psi for air.

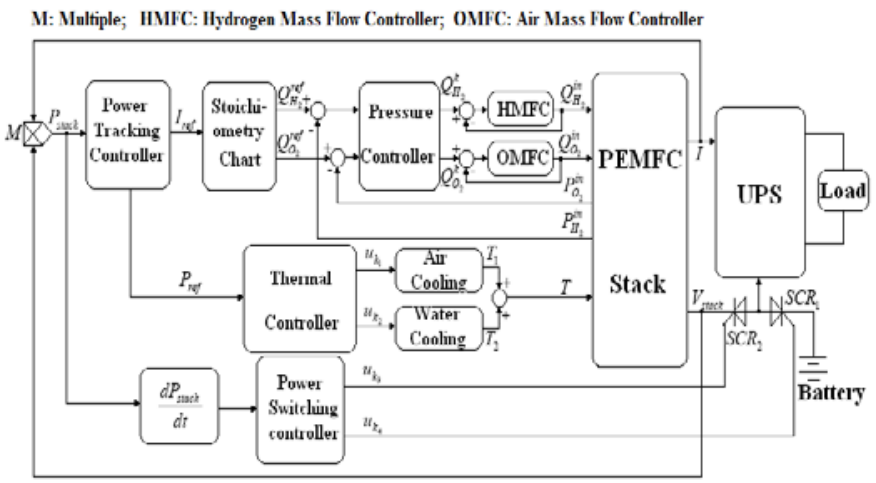

Figure 2. Configuration of a PEMFC powered system for UPS application

\section{A. Power Tracking Controller}

According to the real-time current and voltage of PEMFC stack, the power density (ranging from 12 to $500 \mathrm{~W}$ ) can be firstly calculated. The output power of the fuel cell stack can be calculated by

$$
P_{\text {stack }}=V_{\text {stack }} I
$$

where $P_{\text {stack }}, V_{\text {stack }}$ and $I$ are the output power, voltage and current of the stack, respectively.

The operating point is at the intersection of the PEMFC power curve and the load power curve, as shown in Fig. 3, which shows the voltage-current and power-current characteristics of the PEMFC stack.

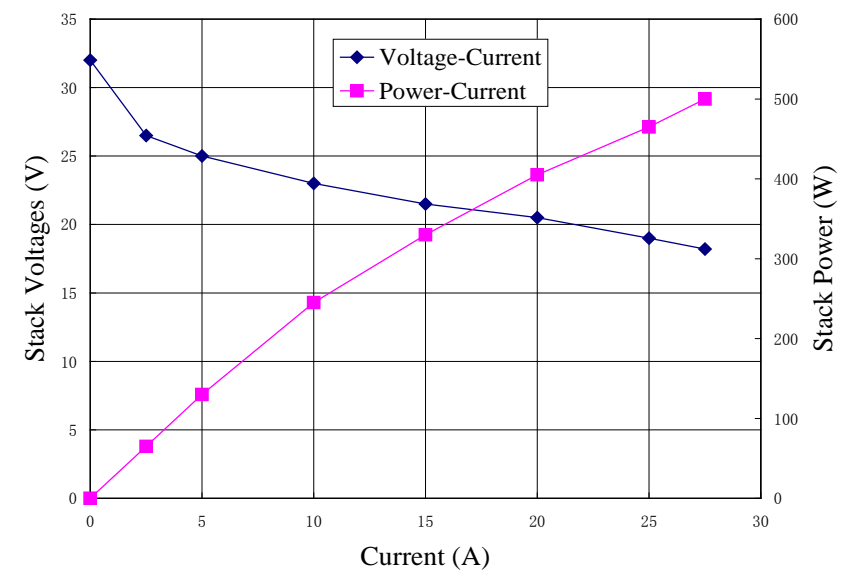

Figure 3. Voltage-current and power-current characteristics of the PEMFC

Based on the load at that time, a power tracking controller is designed to continuously distribute the current or real time power by using the setup value of the reference mass flow $Q^{r e f}{ }_{H 2}$ and $Q^{r e f}{ }_{\mathrm{O} 2}$ of hydrogen and oxygen/air and according to the stoichiometry chart of PEMFC. The stoichiometry chart for hydrogen and air flows for a self-humidified PEMFC stack is shown in Table I. If the load is over $500 \mathrm{~W}$, the controller will shut down the system.

TABLE I. STOICHIOMETRY CHART FOR AIR AND HYDROGEN FLOWS

\begin{tabular}{c|c|c|c|c}
\hline \hline \multirow{2}{*}{$\begin{array}{c}\text { Current } \\
(\mathrm{A})\end{array}$} & \multicolumn{2}{|c|}{ Air flow (SL/min) } & \multicolumn{2}{c}{$\mathrm{H}_{2}$ flow (SL/min) } \\
\cline { 2 - 5 } & Sto.=2.0 & Sto. $=2.5$ & Sto. $=1.0$ & Sto. $=1.2$ \\
\hline 5 & 5.6 & 7.0 & 1.1 & 1.3 \\
\hline 10 & 11.2 & 13.9 & 2.2 & 2.7 \\
\hline 15 & 16.7 & 20.9 & 3.3 & 4.0 \\
\hline 20 & 22.3 & 27.8 & 4.5 & 5.3 \\
\hline 25 & 27.8 & 34.8 & 5.6 & 6.7 \\
\hline 30 & 33.4 & 42.1 & 6.7 & 8.0 \\
\hline \hline
\end{tabular}

\section{B. Thermal Controller}

The PEMFC belongs to the low temperature stack $(<100$ ${ }^{\circ} \mathrm{C}$ ) in the fuel cell family, but its operating temperature is still higher than the ambient temperature and should be maintained within an appropriate range. The operating temperature is selected according to the characteristics of the PEMFC provided by the manufacturer. 
At the altitude of sea level, the air bulk from the fans can be calculated roughly as

$$
V_{\text {Fan }}=\frac{1825}{\Delta T} \times P_{\text {stack }}
$$

where $V_{F a n}$ is the air flow in cube inch per minute, and $\Delta T$ is the temperature deference between the inlet and outlet of PEMFC stack

According to the dynamic analysis of the PEMFC, if the entrance pressures of hydrogen and air are constant, the nonlinear equation of the stack under the operating temperature can be expressed as

$$
T(t)=f\left(U_{w}(t), T_{w}(t)\right)
$$

where $U_{W}(t)$ is the velocity of cooling water in $\mathrm{m} / \mathrm{s}$, and $T_{W}(t)$ is the entrance temperature of cooling water.

For the PEMFC studied, the optimal operating temperature is within $60 \sim 65^{\circ} \mathrm{C}$. In this paper, two kinds of cooling method are used: air cooling and water cooling. Under the low current and power $(<200 \mathrm{~W})$, it is possible to use the air cooling to obtain a satisfactory result. However, when operating in high current and power, the stack should adopt the water cooling. The heat management system of PEMFC will be given in the next section. The experiment proves that it is necessary to have an effective heat dissipation to prevent the fuel cell from high temperature and the proton exchange membrane from dehydration.

The thermal control rules are: (1) If $P_{\text {stack }}$ is less than $200 \mathrm{~W}$ and $T_{\text {stack }}$ is less than $60{ }^{\circ} \mathrm{C}$, air cooling is used, i.e. $\mathrm{u}_{\mathrm{k} 1}=1$ and $\mathrm{u}_{\mathrm{k} 2}=0$; (2) If $P_{\text {stack }}$ is over $200 \mathrm{~W}$ and $T_{\text {stack }}$ is less than $65{ }^{\circ} \mathrm{C}$, both air cooling and water cooling are used, i.e. $\mathrm{u}_{\mathrm{k} 1}=1$ and $\mathrm{u}_{\mathrm{k} 2}=1$; (3) If $P_{\text {stack }}$ is over $500 \mathrm{~W}$ or $T_{\text {stack }}$ is over $65^{\circ} \mathrm{C}$, the PEMFC is shut down.

\section{Fuzzy Logic Controller of Mass Flows}

The fuzzy-PI controller input variables are the mass flow error $e(k)$ and the change of error $c(k)$ of hydrogen or air. The output variables of the controller are the optimal $P$ and $I$ gains of a subsequent PI controller device; one of them gives the proportional part $K$ as a function of $e(k)$ and $c(k)$, and the other gives the increment $\Delta T$, which is then integrated to provide the integral term $T$ of the PI controller. There are the seven fuzzy subsets: positive big (PB), positive medium (PM), positive small (PS), zero (ZE), negative small (NS), negative medium (NM), and negative big (NB), which have been selected for the input and output variables $e(k), c(k), K$ and $T$. The fuzzy control rules are obtained from the behavior analysis of the PEMFC system. Because the rule-base represents the intelligence of the controller, the formulations must be carefully considered. Correct use of control laws according to the operating conditions can greatly improve the system stability. A fast response with a small overshoot for the PEMFC system can be achieved with proper handling of the proportional and integral parts. As described in [14], the fuzzy-
PI controller is more advantageous than a standard PI controller.

The selected control rules or laws are described as follows:

1) Far from the voltage set point: When the output voltage is far from the set point $(\mathrm{e}(\mathrm{k})$ is $\mathrm{PB}$ or $\mathrm{NB})$, the corrective action must be strong; this means that $\mathrm{K}$ should be NB (or $\mathrm{PB}$ ) while $\mathrm{T}$ should be zero (ZE), in order to prevent the continuous increase (or decrease) of integral term that would cause overshoots. In this case, the change of error plays little part.

The basic control rules are summarized as:

If $\mathrm{e}(\mathrm{k})$ is $\mathrm{PB}$, then $\mathrm{K}$ is $\mathrm{PB}$ and $\mathrm{T}$ is $\mathrm{ZE}$;

If $e(k)$ is $N B$, then $K$ is $N B$ and $T$ is $Z E$.

2) Close to the voltage set point: In this region, the change of error must be properly taken into account in order to ensure stability and speed of response. The goal of the fuzzy controller is to achieve a satisfactory dynamic performance with small sensitivity to parameter variations

The control rules are summarized as:

If both $\mathrm{e}(\mathrm{k})$ and $\mathrm{c}(\mathrm{k})$ are $\mathrm{ZE}$, then $\mathrm{K}$ and $\mathrm{T}$ are $\mathrm{ZE}$;

If both $\mathrm{e}(\mathrm{k})$ and $\mathrm{c}(\mathrm{k})$ is negative, $\mathrm{K}$ and $\mathrm{T}$ are negative;

If both $\mathrm{e}(\mathrm{k})$ and $\mathrm{c}(\mathrm{k})$ is positive, $\mathrm{K}$ and $\mathrm{T}$ are positives.

\section{Pressure Controller}

An increase in PEMFC operating pressure results in higher cell voltage according to the Nernst equation and the increase in exchange current density due to increased concentration of reactant gases in the PEMFC electrodes. According to the demands of the PEMFC, this paper adopts the steady pressure equipment to control the reactant gas pressure. The system can also control the hydrogen pressure at about $34.5 \mathrm{kPa}$ (5 psi). An air compressor is used to feed air. After the gas pressure reaches the predetermined value, the air quantity in the air compressor should be controlled according to the rate of utilizable air and the operational current of the stack decided by the experiment. The air pressure value is adjusted to around $68.9 \mathrm{kPa}(10 \mathrm{psi})$.

In the PEMFC system, the relation between the pressure (the controlled variable) and the gas flow (the controlling variable) is one-order inertia tache and purely delayed tache arrayed in series, so the digital proportion integral differential (PID) control is the best method. Furthermore, since the control parameters $K_{P}, T_{I}$ and $T_{D}$ are independent to each other, they can be adjusted conveniently.

The control method of PID is used in the pressure controller, that is, the hydrogen output controlling variable is:

$$
\begin{aligned}
Q_{H_{2}}^{k} & =K_{P} e_{H_{2}}(k T)+\frac{T}{T_{I}} \sum_{j}^{k} e(j T) \\
& +\frac{T_{D}}{T}\left[e_{H_{2}}(k T)-e_{H_{2}}(k T-T)\right]
\end{aligned}
$$

where $T$ is the sample cycle and

$$
e_{H_{2}}(k T)=Q_{H_{2}}^{r e f}(k T)-P_{H_{2}}^{i n}(k T)
$$


In the same way, the air controlling variable can be calculated.

\section{E. Power Switch Controller}

The complex electrode phenomenon existing in the PEMFC is caused by the double charge layer. This acts as a capacitance and gives the fuel cell stack a smooth dynamic voltage output. When the load of the fuel cell stack changes, the voltage output has an initial Ohmic voltage loss due to the resistance of the fuel cell stack and then it slowly moves to a new value. When the load is suddenly increased, the fuel cell may not be able to provide sufficient hydrogen and air to sustain the operation under the new load condition. This can lead to temporary hydrogen and air starvation, thereby causing irreversible damage of the PEMFC stack. To avoid this, in this paper a power switch controller is designed, which can control the power source of UPS to be switched from PEMFC to battery according to the change rate of the power of the PEMFC stack. Transient issues associated with temporary hydrogen and air starvation can be avoided by supplying the power from the battery and slowing down the current drawn from the PEMFC through a change rate limiter of the output power.

The control rules are

$$
\begin{aligned}
& \text { If } d P_{\text {stack }} / d_{t}<50 \% \text {, then } \mathrm{u}_{\mathrm{k} 3}=1 \text { and } \mathrm{u}_{\mathrm{k} 4}=0 \text {; } \\
& \text { If } d P_{\text {stack }} / d_{t} \geq 50 \% \text {, then } \mathrm{u}_{\mathrm{k} 3}=0 \text { and } \mathrm{u}_{\mathrm{k} 4}=1 \text {; } \\
& \text { If } V_{\text {battery }}<30 \mathrm{~V} \text {, then } \mathrm{u}_{\mathrm{k} 3}=1 \text { and } \mathrm{u}_{\mathrm{k} 4}=1 \text {; }
\end{aligned}
$$

\section{DESIGN OF POWER CONVERTERS FOR UPS}

\section{A. Power Converters}

The power converters, which convert the original power into useable power for different applications, are the major components of an UPS hybrid system. The power conditioning system (PCS) controls the voltage's frequency and maintains harmonics to an acceptable level. When the input voltage is under the normal state of utility grid power source (160 275 $\mathrm{VAC}$ ), an active power factor corrector (PFC) AC/DC rectifier converts the AC voltage into DC voltages of $\pm 380 \mathrm{~V}$ (BUS). When the utility input fails, the PEMFC and battery supply the power sources for UPS immediately. The function of power converters is to adapt the electrical current from PEMFC to suit the electrical needs of the applications.

According to the design concepts as mentioned above, the proposed topology of power converters, or the power conditioners, is shown in Fig. 4. According to its functionality, the system can be considered as being composed by three main sections. The first consists of a DC/DC converter whose principal task is to boost the rated output voltage of 36 VDC of PEMFC and battery to a regulated \pm 380 VDC. The second is an AC/DC rectifier which rectifies the utility input voltage into \pm 380 VDC. The third section is a DC/AC inverter which generates an output voltage of $50 \mathrm{~Hz}, 220 \mathrm{VAC}$ RMS.

In the developed UPS hybrid system, by applying the TMS320F240 DSP, a DC/AC half-bridge inverter is designed to supply the load with a pure sine wave, as shown in Fig. 4, where the half-bridge inverter, LC filter and load are considered as the plant to be controlled. Since the switching frequency (designed operational frequency $=20 \mathrm{kHz}$ ) is much higher than the natural frequency and modulation frequency, the dynamics of the DC/AC inverter are mainly determined by its LC filter. Dead-time effect and inevitable loss in each part of the DC/AC inverter cause little damping. The damping effect can be considered by using a small resistor connected in series with the filter inductor. Through the sine pulse width model (SPWM) control, the DC/AC inverter can convert the \pm 380 VDC into a 220 VAC pure sine wave.

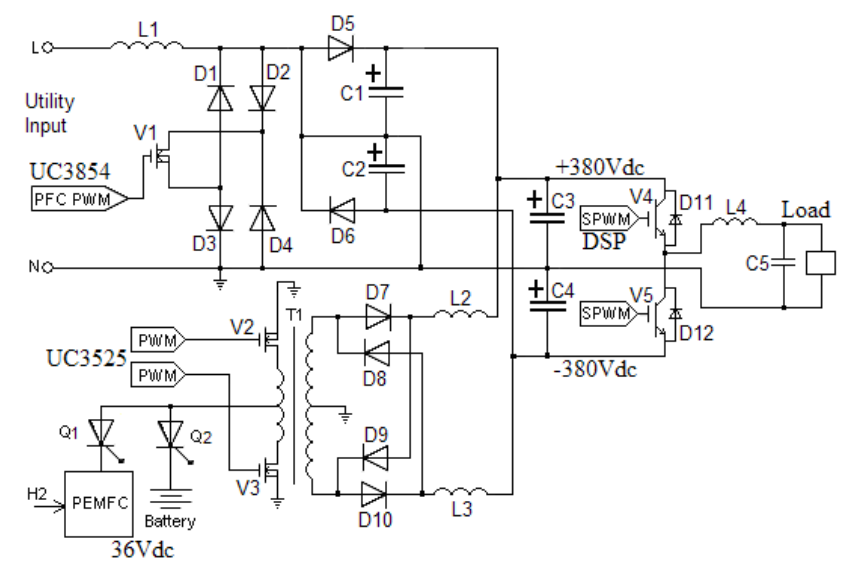

Figure 4. Power converters for a hybrid UPS system

A general and practical DC/DC push-pull converter for the UPS hybrid system is designed based on a regulating pulse width modulator UC3525. The PEMFC and battery are two kinds of low-voltage and high-current power source, so their output voltage (36 VDC) should be boosted up to about \pm 380 VDC before the UPS DC/AC inverter converts them into a 220 $\mathrm{V}, 50 \mathrm{~Hz}$ AC source. This boosting action is performed by the DC/DC converter. Fig. 4 shows the schematic diagram of the converter. The operating frequency of power switches $V_{2}$ and $\mathrm{V}_{3}$ is $20 \mathrm{kHz}$.

A boost active power factor corrector (PFC) with 160-275 VAC input voltage and fixed output voltage $( \pm \mathrm{BUS}= \pm 380 \mathrm{~V}$ $\mathrm{DC}$ ) is designed based on a high power factor pre-regular UC3854, which can make the input power factor (PF) of the AC/DC boost PWM rectifier be close to 1 , restrict the input current's THD less than 5\%, adopt the average current control and constant frequency control, and allow the frequency band of its current amplifier to be wide. Fig. 4 shows the singlephase active PFC AC/DC rectifier and its working pattern. The operational frequency of UC3854 is $100 \mathrm{kHz}$.

\section{B. Control Strategy of Power Converters}

The design of the AC/DC, DC/DC, and DC/AC power converters is simple and cost effective, which allows a simple PEMFC energy management and a low voltage battery pack. As far as the PEMFC output characteristic is that of a current controlled voltage source, and the output of the PEMFC is an unregulated DC voltage varying against the current and load, it needs to be conditioned for practical use. The PEMFC output power can be regulated by means of a current control.

The block diagrams of the power converters with the control strategies incorporated are shown in Figs. 5 and 6. 
There are three separate control loops for the AC/DC rectifier control, the DC/DC converter control, and the DC/AC inverter control.

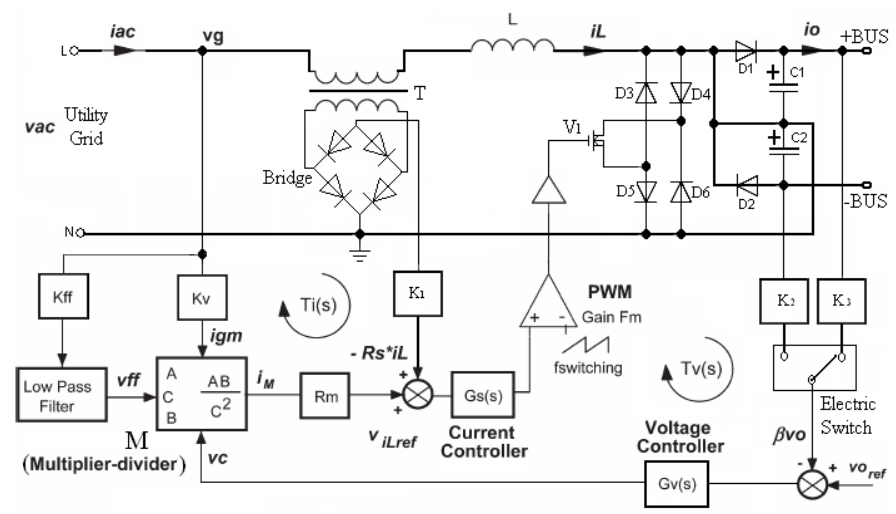

Figure 5. Schematic diagram of boost AC/DC rectifier

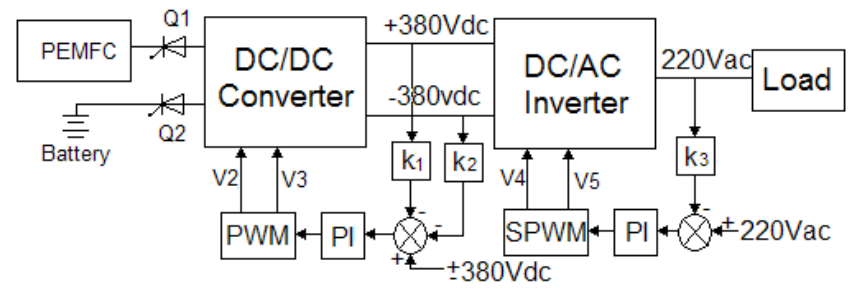

Figure 6. Schematic diagram of DC/DC and DC/AC power converters

\section{1) $A C / D C$ rectifier}

The active PFC rectifier based on a boost converter is one of the most popular single-phase topologies used in practice to fulfill the standards on power factor and input current distortion of power supplies. For example, active PFC circuits using the boost converter configuration have been widely employed in the design of single-phase power supplies. Their advantages include wide work range of AC voltage, high voltage stability allowing the use of small capacitance to meet the need of holding time, PF improvement with a typical value of larger than 0.98 , and reduction of the THD factor with a typical value of less than 5\%. In large power equipments, three phase AC/DC converters with more complex topologies and controls are commonly used, as the harmonic pollution can be more serious.

Fig. 5 illustrates the schematic diagram of the boost active PFC controlled by UC3854, where $\mathrm{T}_{\mathrm{I}}(\mathrm{s})$ is a current control loop, $\mathrm{T}_{\mathrm{V}}(\mathrm{s})$ is a voltage control loop, and $\mathrm{M}$ is a multiplierdivider $[15,16]$. With the action of the initiative switch (PFC MOSFET), it can modify the input current to sine wave, which follows and changes with the input voltage $\left(V_{i n}\right)$, so it can achieve the goal of unity PF.

The output signal $I_{m}$ of the multiplier-divider $\mathrm{M}$ is the standard current, which can be calculated by

$$
I_{m}=\frac{I_{A C}\left(V_{A O}-1.5\right)}{V_{r m s}^{2}}
$$

where $I_{A C}$ is the multiplier's input current which is about 250 $\mu \mathrm{A}$ and comes from $V_{i n}, V_{A O}$ is the output voltage of the voltage error amplifier, and $V_{r m s}$ is the feed-forward voltage which is about 1.50-4.77 $\mathrm{V}$ and is provided with the partition of the active PFC $V_{i n}$.

Under the state of main supply (160-275V), the active PFC MOSFET $V_{1}$ is in the "off" state, and the positive and negative BUS voltages are built with filtering through the inductance $\mathrm{L}$ and capacitances $C_{1}$ and $C_{2}$. Because the inductance value is small here, the BUS voltage can be estimated by

$$
V_{B U S}=\sqrt{2} V_{i n}
$$

When the UPS operates, $T_{1}$ turns on or off, for chopping the wave. The positive and negative BUS voltages increase to the typical steady values of about \pm 380 VDC. When the inductance current is continuous, the BUS voltage can be calculated by

$$
V_{\text {BUS }}=\frac{1}{1-D} V_{\text {in }}
$$

where the conduction duty cycle

$$
D=\frac{T_{\text {ON }}}{T_{\text {ON }}+T_{\text {OFF }}}<1
$$

When the inductance current is discontinuous, the BUS voltage is estimated by

$$
V_{B U S}=V_{i n}+\frac{\left(V_{i n} D\right)^{2}}{2 L_{1} I_{0} f_{s}}
$$

where $L_{1}$ is the inductance, $I_{0}$ the load current, and $f_{s}$ the operating frequency.

\section{2) $D C / D C$ converter}

The proposed DC/DC converter is a push-pull converter which works in the double state of polarity. At the design stage, it is important to effectively avoid the iron core saturation. Its circuit diagram is shown in Fig. 4. Since there are two switches: $\mathrm{V}_{2}$ and $\mathrm{V}_{3}$, which work alternately, the output voltage $V_{0}$ is doubled. Under the condition of continuous current, the output voltage is calculated by

$$
V_{0}=D N V_{\text {in }}
$$

where $N$ is the transformer turn ratio, $D$ the conduction duty cycle and $D=2 T_{o n} / T_{S}, T_{S}$ the operation period, and $V_{\text {in }}$ the input voltage from the PEMFC stack and battery.

When the current is discontinuous, the output voltage is determined by 


$$
V_{0}=\frac{V_{i n}^{2} D^{2} N^{2} T_{s}}{4 L_{1} I_{0}+V_{i n} D N T_{S}}
$$

\section{3) DC/AC inverter}

In Fig. 4, when the switch $V_{4}$ is turned on for a time period of $T / 2$, the instantaneous voltage across the load is +BUS $=380$ VDC. On the other hand, if the switch $V_{5}$ is turned on for a time period of $T / 2$, the instantaneous voltage across the load is - BUS $=380$ VDC. The control circuit is designed in such a way that $V_{4}$ and $V_{5}$ are not on at the same time. The typical output voltage waveform for the circuit arrangement of Fig. 4 is as depicted in Fig. 7.

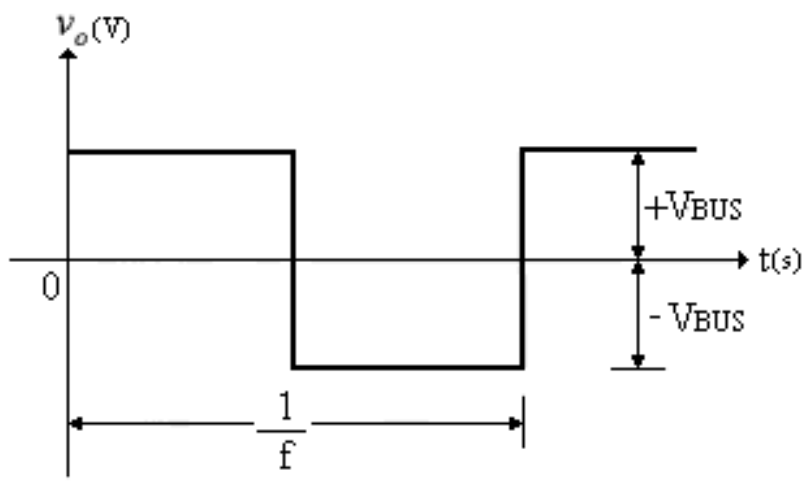

Figure 7. Basic square wave output voltage waveform

The designed single-phase DC/AC inverter of Fig. 4 is a half-bridge inverter and its RMS output voltage is calculated from Fig. 7 as

$$
v_{0}=\sqrt{\frac{2}{T} \int_{0}^{T / 2} \frac{V_{S}^{2}}{4}} d t=V_{B U S}
$$

Furthermore, the instantaneous output voltage can be expressed in a Fourier series as

$$
v_{0}=\sum_{1,3,5, \cdots}^{\infty} \frac{2 V_{s}}{n \pi} \operatorname{Sin}(n \omega t)
$$

where $\omega$ is the angular frequency of the output voltage in $\mathrm{rad} / \mathrm{s}$. The output voltage of a practical inverter is not purely sinusoidal, i.e. it contains harmonics, which distort the waveform. Hence, the quality of power achieved from practical inverters needs to be improved by the usage of suitable output LC filter, which consists of the inductance $\mathrm{L}_{4}$ and the capacitance $\mathrm{C}_{5}$ as in Fig. 4.

\section{Energy Storage Components}

As mentioned above, the energy storage unit such as battery and ultracapacitor is one of the key elements in the UPS hybrid system. The PEMFC plays the role of main power supply under normal conditions, and the battery or ultracapacitor provides the rest of the power when overload is necessary or when the PEMFC starts up or when the load changes sharply. Compared to conventional batteries, the ultracapacitor has some advantages such as higher power density, higher pulse current, smaller size and the possibility to be used in an active filter [17]. On the other hand, ultracapacitors are still very expensive for industrial application.

The use of two power sources, performing with different characteristics, implies the need of size optimization of two sources. An accurate design of the electronic converter is required for exploiting a suitable control strategy, which must allow the management of power flows while performing high efficiency and low cost. In this UPS hybrid system, the AC/DC charger (under the normal state) and the PEMFC stack duty (under the utility grid failure) must be properly controlled in order to charge the batteries when the state of charge (SOC) is less than 0.8. A set of three $12 \mathrm{~V}, 7.2 \mathrm{Ah}$ PANASONIC batteries with high discharge current have been chosen for this application, which type and specifications are LC-R127R2CH, $12 \mathrm{~V} / 7.2 \mathrm{Ah} / 20 \mathrm{HR}$, respectively. On the other hand, one may use 15 series-connected ultracapacitors with the main specifications as $1000 \mathrm{~F}( \pm 20 \%)$, control voltage of $2.5 \mathrm{~V}$, and maximum current of $150 \mathrm{~A}$.

\section{EXPERIMENTAL SETUP AND RESULTS}

The performances of the proposed control strategies of PEMFC generating system and hybrid UPS power converters are tested by building an experimental setup with the following specifications: Input voltage of the utility grid of $160 \mathrm{~V} \sim 275 \mathrm{~V}$ AC, output voltage frequency of $50 \mathrm{~Hz} \pm 5 \%$, PEMFC/battery rated voltage of $36 \mathrm{VDC}$, and output power of $286 \mathrm{~W}$. The experimental load is a DELL ${ }^{\mathrm{TM}}$ computer, whose model is HP$\mathrm{U} 2106 \mathrm{~F} 3$, and the maximum input power is $213 \mathrm{~W}$, and a monitor, whose model is E772p with power of $73 \mathrm{~W}$. Moreover, a lamp box is used as the supplementary load. Agilent Technologies DSO6034A Oscilloscope, TEKTRONIX AM503 current probe amplifier and P5120 high voltage differential probe are employed as measurement equipments.

Fig. 8 shows the voltages and currents of PEMFC and battery power sources for supplying UPS, and Fig. 9 shows that when the PEMFC charges the battery.

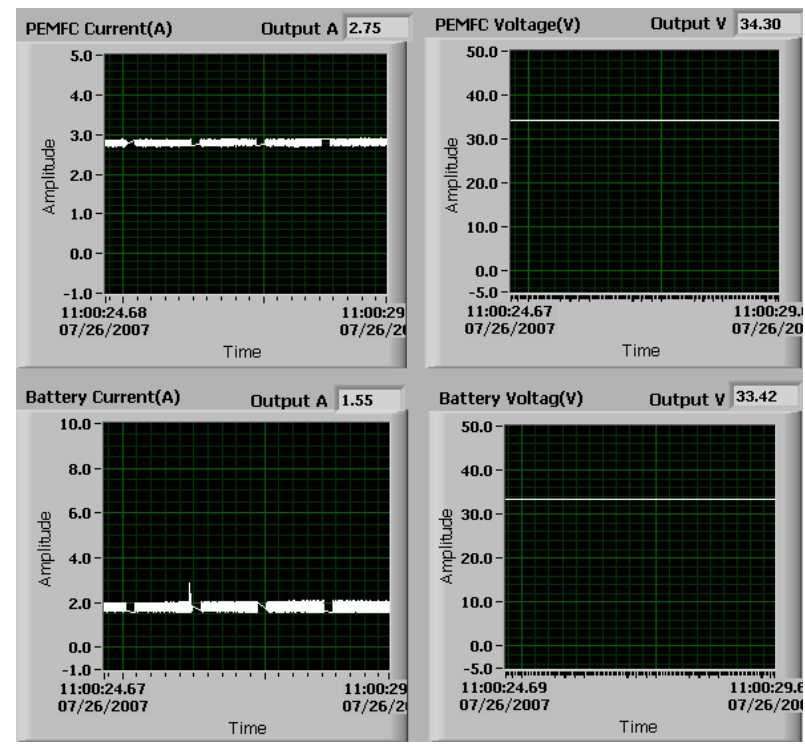

Figure 8. Voltage and current of PEMFC and battery under a computer load 


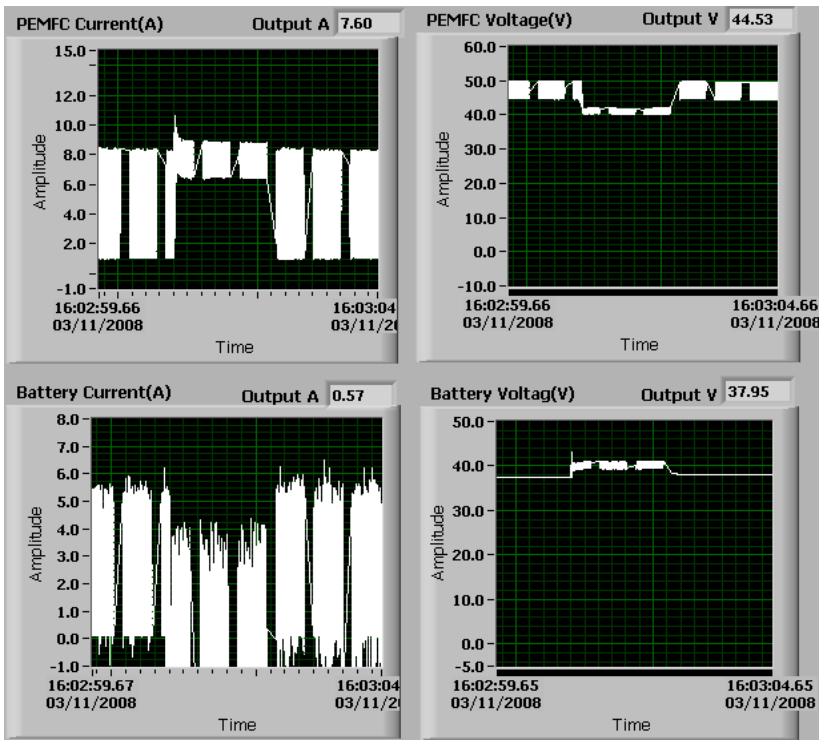

Figure 9. Voltage and current when the PEMFC charges the battery

Fig. 10 gives the gate control signals of the DC/DC converter and the $36 \mathrm{~V} / 380 \mathrm{~V}$ push-pull converter modulation. The change of output voltage of DC/DC converter and the regulation of the BUS DC voltage are reported in Fig. 11, when the utility input failures and PEMFC supplies UPS. Fig. 12 plots the experimental waveform of the input voltage and current of UPS when utility grid is normal. The output voltage and current of the DC/AC inverter can be observed in Fig. 13.

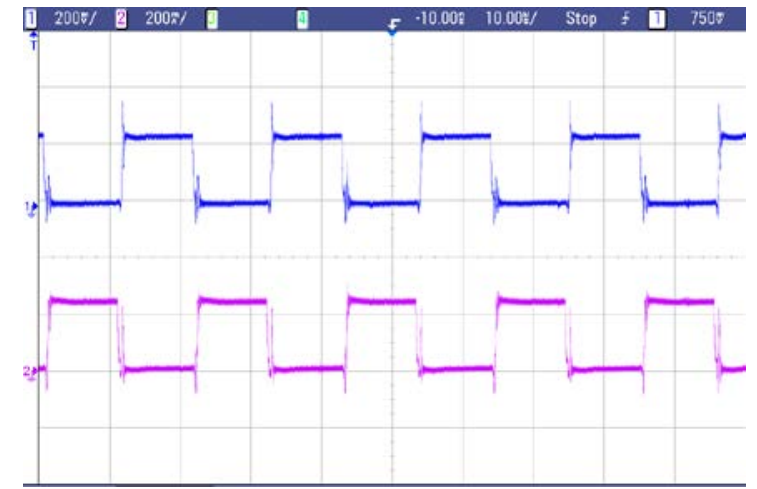

Figure 10. PWM gate control signals of DC/DC converter (ch1, ch2)

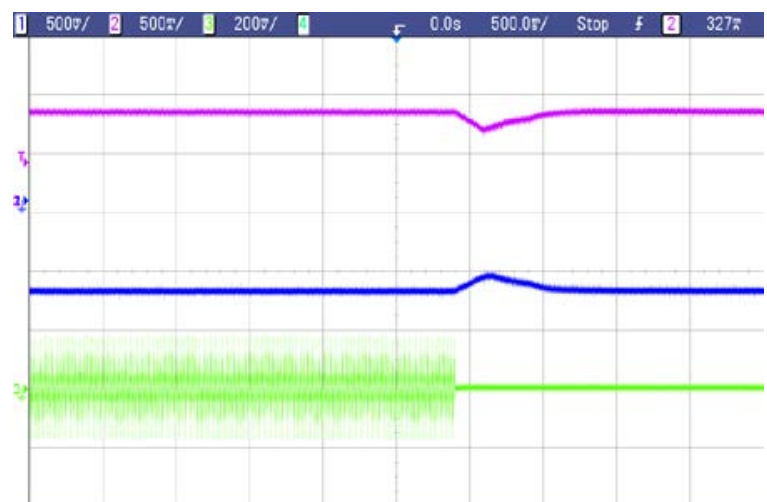

Figure 11. Output voltage (ch1, ch2) of DC/DC converter when the utility input failures (ch3) and PEMFC supplies power

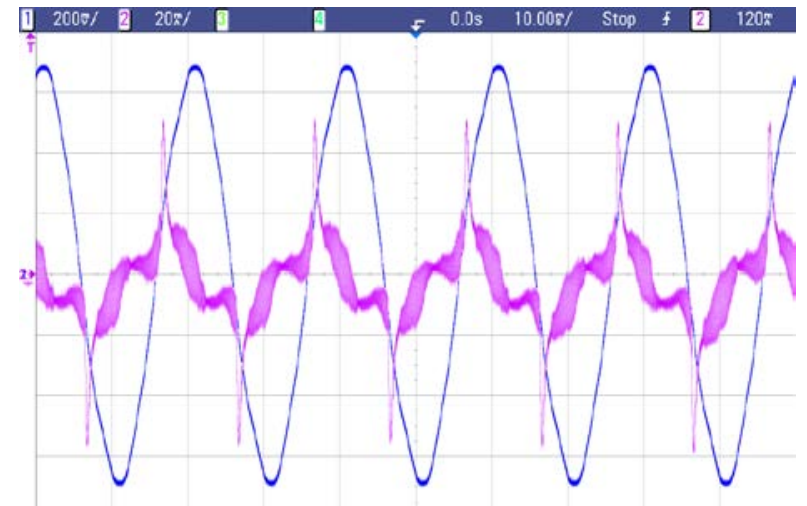

Figure 12. Input voltage (ch1) and current (ch2) of UPS with normal utility grid

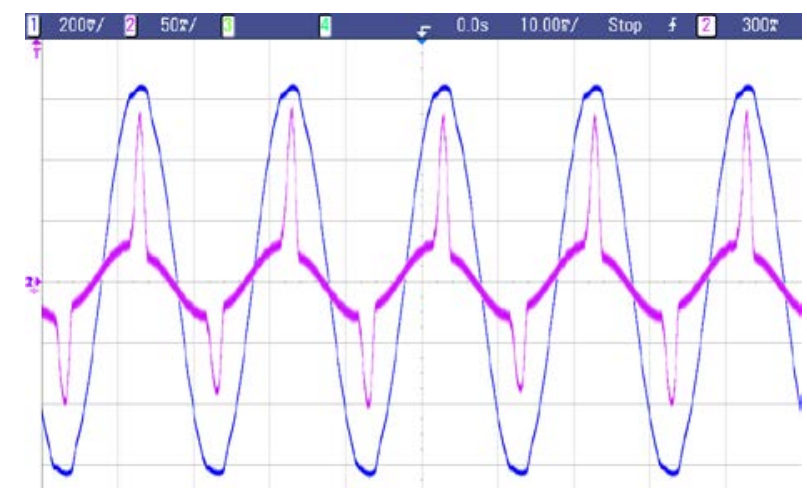

Figure 13. Output voltage (ch1) and current (ch2) of UPS when supplied by PEMFC

\section{CONCLUSION}

This paper presents the power converters and comprehensive controller for a UPS with backup hybrid PEMFC and battery power sources, in which cost effective and practical DC/DC converter, DC/AC inverter and AC/DC rectifier are designed to feed a typical computer load $(220 \mathrm{~V}$, $50 \mathrm{~Hz}$ ). The proposed topologies allow us to process the energy produced by the PEMFC independently and in parallel to that of batteries. An experimental evaluation has been carried out, and the performances have been tested. The experimental results show that the designed converters and controller are practical for industry applications.

\section{REFERENCES}

[1] F. Alessandro, V. Antonucci, L. Dusonchet, S. Favuzza, M. Ferraro, and G. Graditi, "UPS fuel cell based: an innovative back-up system,” in Proc. Int. Conf. on Clean Electrical Power, May 21-23, 2007, pp. 723-729.

[2] B. Liu, S. Duan, Y. Kang, and J. Chen, "Genetic algorithm optimized fuzzy repetitive controller for low cost UPS inverter application,” in Proc. IEEE Int. Conf. on Electric Machines and Drives, 2005, pp. 840845.

[3] J. Gonzales and G. Tamizhmani. "High efficiency fuel cell based uninterruptible power supply for digital equipment,” Journal of Power Sources, vol. 153, pp. 151-156, 2006.

[4] E. Varkaraki, N. Lymberopoulos, E. Zoulias, D. Guichardot, and G. Poli, "Hydrogen-based uninterruptible power supply," Int. J. of Hydrogen Energy, vol. 32, pp. 1589-1596, 2007. 
[5] E. Varkaraki, N. Lymberopoulos, and A. Zachariou, "Hydrogen based emergency back-up system for telecommunication applications,” Journal of Power Sources, vol. 118, pp.14-22, 2003.

[6] K. Moth and J. D. Schmidt, "APC fuel cell solution for extended run time UPS,” in Proc. $27^{\text {th }}$ Int. Telecommunications Conf., Sept. 2005, pp. 361-365.

[7] J. S. Han and E. S. Park, "Direct methanol fuel-cell combined with a small backup battery,” Journal of Power Sources, vol. 112, pp. 477-483, 2002.

[8] D. K. Choi, B. K. Lee, S. W. Choi, C. Y. Won, and D. W. Yoo, “A novel power conversion circuit for cost-effective battery-fuel cell hybrid systems,” Journal of Power Sources, vol. 152, pp. 245-255, 2005.

[9] W. Choi, J. W. Howzeb, and P. Enjeti, "Fuel-cell powered uninterruptible power supply systems: design considerations,” Journal of Power Sources, vol. 157, pp. 311-317, 2006.

[10] A. D. Napoli, F. Crescimbini, S. Rodo, and L. Solero, "Multiple input DC-DC power converter for fuel-cell powered hybrid vehicles,” in Proc. $33^{\text {rd }}$ IEEE Annual Power Electronics Specialists Conf., June 23-27, 2002, pp. 1685-1690.

[11] M. Marchesoni and C. Vacca, "New DC-DC converter for energy storage system interfacing in fuel cell hybrid electric vehicles,” IEEE Trans. Power Electronics, vol. 22, pp. 301-308, 2007.
[12] K. P. Yalamanchili and M. Ferdowsi, "Review of multiple input DC-DC converters for electric and hybrid vehicles,” in Proc. IEEE Conf. on vehicle power and propulsion, Sept. 7-9, 2005, pp. 160-163.

[13] BSC Technology, 500W PEM Fuel Cell Operation Manual, BCS Technology, Inc, Texas, Bryan, 2001.

[14] Y. D. Zhan, J. G. Zhu, Y. G. Guo, and A. Rodriguez, “An intelligent controller for PEM fuel cell power system based on double closed-loop control," in Proc. Australasian Univ. Power Eng. Conf., Hobart, Australia, Sept. 25-28, 2005, pp. 174-179.

[15] E. Figueres, J. M. Benavent, G. Garcera, and M. Pascual, “A control circuit with load-current injection for single-phase power-factorcorrection rectifiers,” IEEE Trans. Industrial Electronics, vol. 54, no. 3, pp. 1272-1281, 2007.

[16] Y. D. Zhan, J. G. Zhu, Y. G. Guo and H. Wang, "Design of an active power factor converter for UPS with backup proton exchange membrane fuel cell/battery,” in Proc. Australasian Univ. Power Eng. Conf., Perth, Australia, Dec. 9-12, 2007, pp. 435-440.

[17] M. Cacciato, F. Caricchi, F. G. Capponi, and E. Santini, “A critical evaluation and design of bi-directional DC/DC converters for supercapacitors interfacing in fuel cell applications," in Proc. IEEE $39^{\text {th }}$ Industry Application Society Annual Meeting, Seattle, USA, Oct. 3-7, 2004. 